Dicle Tıp Dergisi / Dicle Med J (2019) 46 (1) : 85 - 90

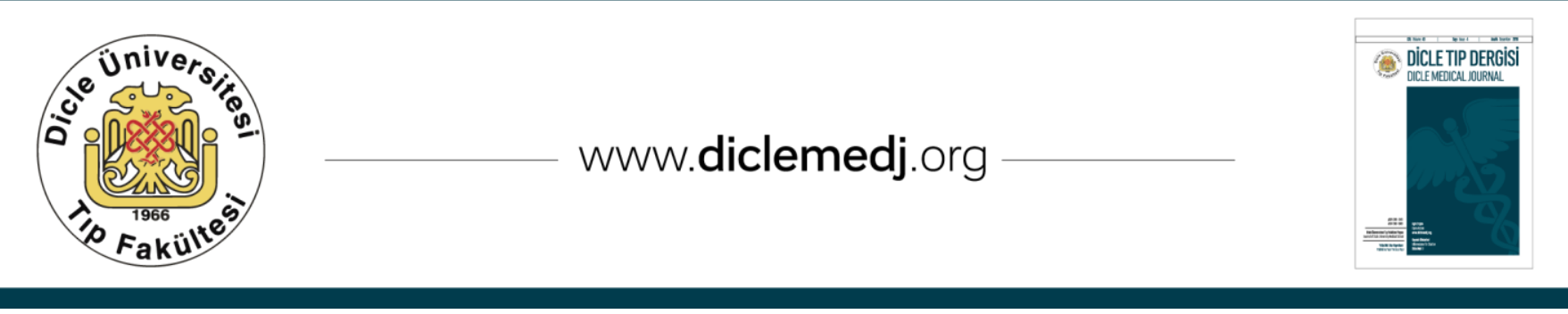

Özgün Araștırma / Original Article

\title{
Which Method is More Effective in Aerochamber Training in Pediatric Age Group?
}

\author{
Mehmet Yaşar Özkars', Serkan Kırık² \\ 1 Kahramanmaras Sutcu Imam University Department of Pediatric Immunology and Allergy Kahramanmaras, Turkey ORCID: 0000-0003-1290-8318 \\ 2 Kahramanmaras Sutcu Imam University Department of Pediatric Neurology Kahramanmaras, Turkey ORCID:0000-0002-8658-2448
}

Received: 13.08.2018; Revised: 13.11.2018; Accepted: 04.01.2019

\begin{abstract}
Objective: Spacer and metered-dose inhaler use is widespread especially among pediatric population. In children, training in medication use is provided both for the family and the child. The aim of the present study was to investigate whether this training is well comprehended and which training method is more effective to achieve that goal.

Methods: This study included patients presenting to our outpatient clinic who were in need of spacer and metereddose inhaler use. The study subjects had an age range of 2-16 years. The patients were randomized into two groups. The first group was trained on metered-dose inhaler use by video demonstration. The second group was trained by applied verbal training. They asked to use spacer and metered-dose inhaler, and they were rated from 0 to 6 , as in previous studies. Errors and deficiencies of use were re-explained. They were informed about their scores and were told that they would be rated again in the next follow-up appointment. They were asked again to use spacer and metered-dose inhaler and rated between 0 and 6 at the second-month control visit.

Results: The intra-group analysis of the video group showed a significant difference between the first-month and second-month total scores $(p<0,01)$. The intra-group analysis of the verbal training group also showed a significant difference between the first-month and second-month total scores $(\mathrm{p}<0,01)$.

Conclusion: In conclusion, we demonstrated the positive effect of actively inclusion of patients with asthma into the training about spacer and metered-dose inhaler use. We ensured active participation by exam motivation. Here in we aimed to contribute to the existing literature.
\end{abstract}

Keywords: Asthma, inhaler technique, spacers, patient training

DOI: $10.5798 /$ dicletip

Yazışma Adresi / Correspondence: Serkan Kırık, Kahramanmaraş Sütçü İmam Üniversitesi Hastanesi Çocuk Nöroloji Kliniği, 46046 Onikişubat/Kahramanmaraș,Turkey e-mail: srknkrk@hotmail.com 


\section{Aerochamber Eğitiminde Hangi Yöntem Daha Etkili?}

\section{Öz}

Amaç: Hazne ve ölçülü doz inhaler kullanımı özellikle pediatrik yaş grubunda yaygındır. Çocuklarda ilaç kullanımı eğitimi hem aileye hem çocuğa verilmektedir. Çalışmamızın amacı; verdiğimiz bu eğitimin anlaşılıp anlaşılmadığının belirlenmesi ve hangi eğitim yönteminin daha faydalı olduğunun belirlenmesidir.

Yöntemler: Çalışmaya alerji polikliniğimize başvuran hazne ve ölçülü doz inhaler kullanması gereken hastalar alındı. Hastalarımız 2-16 yaş arası çocuklardan oluşmaktaydı. Hastalar rastgele iki gruba ayrıldı. Birinci gruba hazne ve ölçülü doz inhaler kullanımı video gösterimi ile öğretildi. İkinci gruba ise uygulamalı sözel anlatım ile öğretildi. Hastaların hazne ve ölçülü doz inhaleri kullanması istendi ve daha önceki çalışmalara benzer şekilde 0-6 puan arası olarak not verildi. Uygulamadaki hatalar ve eksiklikler yeniden anlatıldı. Aldıkları puanlar kendilerine söylendi ve 1 ay sonra yeniden kontrole geldiklerinde aynı puanlamanın tekrar yapılacağı belirtildi. İkinci ay kontrolünde yeniden hastaların hazne ve ölçülü doz inhaleri kullanması istendi ve 0-6 puan arası olarak not verildi.

Sonuçlar: Video grubunun kendi içerisinde yapılan incelemelerde birinci ay ve ikinci ay total skorları arasında belirgin anlamlı fark vardı $(\mathrm{p}<0,01)$. Sözel anlatım grubunun da kendi içerisinde yapılan incelemelerde birinci ay ve ikinci ay total skorları arasında belirgin anlamlı fark vardı $(\mathrm{p}<0,01)$.

Tartışma: Sonuç olarak biz astımda hastaların hazne ve ölçülü doz inhaler kullanımı eğitiminde hastaları sürece aktif olarak dahil etmenin pozitif sonuçlarını göstermiş olduk. Aktif katılımı ise sınav motivasyonu ile sağladık. Amacımız astım tedavisinin önemli bir basamağı olan hasta eğitimi konusunda literatüre katkıda bulunmaktır.

Anahtar kelimeler: Astım, inhaler teknik, hazne, hasta eğitimi.

\section{INTRODUCTION}

Metered-dose inhaler use is the most commonly used treatment for asthma ${ }^{1}$. However, sometimes it may prove difficult to learn the proper technique of medication use. Therefore, errors of medication use are very common ${ }^{2}$. An improper technique of medication use will prevent a medication from reaching airways and exerting its effects, which will preclude asthma control ${ }^{3}$. This means that asthma patients will have shortcomings in the clinics. As a result, asthma control will be difficult. We have more urgent applications and more treatment cost problems. Sanchis et al reviewed 144 studies published in a period of 40 years that comprised 54354 subjects 4 . They reported inappropriate techniques of inhaler use and no improvement of errors of medication use within that period. That is, errors of medication use remain exactly the same as they were 40 years ago. The authors concluded that novel approaches for medication use.
Use of spacer and metered-dose inhalers is common particularly among pediatric age group 5 . Training about medication use is provided for both children and families. One of the techniques used for this training is the verbal training technique. Practical demonstration of the use in combination with verbal training facilitates comprehension. Another technique used for this purpose is the video demonstration technique. We use practical demonstration and video demonstration while verbally instructing patients. The goal of our study was to determine whether our training is well absorbed by the patients and which of these two techniques was more beneficial to reach that goal.

\section{METHODS}

This study includes patients who had been recently diagnosed with asthma and required to use spacer and metered-dose (216 patients, 100 females, 116 males). The study period was between 15.07.2017-15-11.2017 dates. Our 
study was conducted at a university hospital in a city center of a metropolitan area in the eastern Mediterranean Region. The age range of the study population was 2-16 years. Patients with non-asthmatic chronic disorders were excluded. An additional 12 patients were excluded due to being lost to follow-up. All patients or their families gave informed consent. The patients were randomized into two groups. The first group of patients (104 patients, 44 females, 60 males) were trained about spacer and metered-dose inhaler use with video demonstration. The second group (112 patients, 56 females, 56 males) were trained about spacer and metered-dose inhaler use with applied verbal training. The patients were called for a control visit 1 month later. At that control visit they were applied a 6-item application control with face-to-face interview presented in Table 1 . The patients were asked to use metered-dose inhaler and rated with a score ranging between 0 and 6 . For the preparation of scoring questions; Türkeli A et al questions have been modified ${ }^{6}$. Errors and deficiencies of use were re-explained. Their scores were told and they were informed that the same rating would be applied at the second visit one month later. The patients were asked to use metered-dose inhaler and rated with a score ranging between 0 and 6 at the secondmonth control. Approval was obtained from the Kahramanmaras Sutcu imam University, Faculty of Medicine, Clinical Researches Ethics Committee (date: 05.07.2017, number: 2017/11). All observation and trainings were performed by a single investigator who is a pediatric allergy diseases specialist. The SPSS 21 program was used for statistical analyses. The One Way Anova Test and Paired Sample $t$ Test were used for assessments to evaluate the between variables. Statistical significance was established as $\mathrm{p}<0.05$.
Table 1: Questions asked at the rating of Spacer and metered-dose inhaler use.

\begin{tabular}{|llcc|}
\hline Question & Yes & No \\
$\mathbf{1}$ & $\begin{array}{l}\text { Did he/she properly placed the aerochamber device } \\
\text { into his/her mouth? }\end{array}$ & 1 & 0 \\
$\mathbf{2}$ & $\begin{array}{l}\text { Did he/she properly placed the medication into the } \\
\text { aerochamber? }\end{array}$ & 1 & 0 \\
$\mathbf{3}$ & Did he/she shake the medication before puffing it? & 1 & 0 \\
$\mathbf{4}$ & $\begin{array}{l}\text { Did he/she understand the inhaling technique well? } \\
\text { Does he/she know how to use more than one puff } \\
\text { when needed? }\end{array}$ & 1 & 0 \\
$\mathbf{6}$ & $\begin{array}{l}\text { Does he/shegargle after finishing with the } \\
\text { medication? }\end{array}$ & 1 & 0 \\
\hline
\end{tabular}

\section{RESULTS}

There were no significant differences between demographic characteristics of the study subjects presented in Table 2 .

Table 2: Demographic properties of the volunteer group. (Maternal Education Status: 1-Primary School 2-Middle School 3-High School 4-University)

\begin{tabular}{|c|c|c|c|}
\hline & $\begin{array}{l}\text { Video Group } \\
\text { (n:104) }\end{array}$ & $\begin{array}{l}\text { Verbal Training } \\
\text { Group (n:112) }\end{array}$ & $\mathbf{p}$ \\
\hline Age (years)* & $7,67 \pm 2,7$ & $7,36 \pm 2,5$ & $\mathbf{0 , 3 8 8 ^ { 1 }}$ \\
\hline $\begin{array}{l}\text { Gender } \\
\text { (Female/Male) }\end{array}$ & $44 / 60$ & $56 / 56$ & $0,276^{2}$ \\
\hline $\begin{array}{l}\text { Maternal } \\
\text { Education Status* }\end{array}$ & $1,96 \pm 1,07$ & $2,04 \pm 1,12$ & $0,621^{1}$ \\
\hline
\end{tabular}

*mean \pm standart deviation, 1One-Way Annova Test, 2 Chi-Square Test

There were no statistically significant differences between mean total scores of the video group and verbal training group at both 1. month and 2. Month ( $p=0,831$ and $p=0,727$ respectively, One Way Anova Test) (Table 3). An intra-group analysis of the video group revealed significant differences between the first and second-month scores $(\mathrm{p}<0,01$. Paired Samples $t$ Test). The verbal training group also showed significant difference between the first and second-month scores presented in Table 3 $(p<0,01$. Paired Samples t Test). 
In Figure 1, the comparison of the total scores of the groups at the first and second months revealed similar results shown.

Table 3: Scores of the volunteers.

\begin{tabular}{|llll|}
\hline & \multicolumn{3}{c|}{ Video Group Verbal training } \\
& $(\mathbf{n : 1 0 4})$ & group (n:112) & p \\
\hline First-month total score* & $3,79 \pm 1,14$ & $3,82 \pm 1,11$ & $0,831^{1}$ \\
\hline $\begin{array}{l}\text { Second-month total score * } \\
\text { Intra-group difference }\end{array}$ & $5,39 \pm 0,91$ & $5,44 \pm 0,89$ & $0,727^{1}$ \\
between the first and second & $\mathrm{p}<0,01^{2}$ & $\mathrm{p}<0,01^{2}$ & \\
months & & & \\
\hline
\end{tabular}

\section{DISCUSSION}

Inhaler therapy is the cornerstone in asthma7. Many patients use this treatment. Physicians may think that their patients' drug use is correct. But, deficient inhaler technique is a quite common occurrence ${ }^{8}$. Most errors are made with metered-dose inhaler use. In line with the literature, we also found similar use errors in our work. We used "examination" excitement as a novel motivation for learning, and obtained very positive results. Both groups had quite lower learning scores at the end of the first months. Nevertheless, announcing that the same control mechanism would be applied at the second month just like the examination at the first month also led to a positive motivation among the patients. As a result, both groups attained similarly higher learning scores at the second-month control. Oliveira et al reported that medications used for asthma treatment were commonly used with an erroneous technique and suggested that a wellstructured training would be beneficial9,10. Indeed, as Oliveira emphasizes, there has been a significant improvement in the use of our patients with good training. Mason et al, on the other hand, improperly used spacer medications were not as useful as desired is asthma ${ }^{11}$. Similarly, Melani et all pointed to the critical importance of the use of a proper use of inhaler technique. As Mason and Melani point out, if the drug does not act, the disease will not be under control. In our patients, if they were satisfied with the initial education, the patients' asthma could not be controlled.

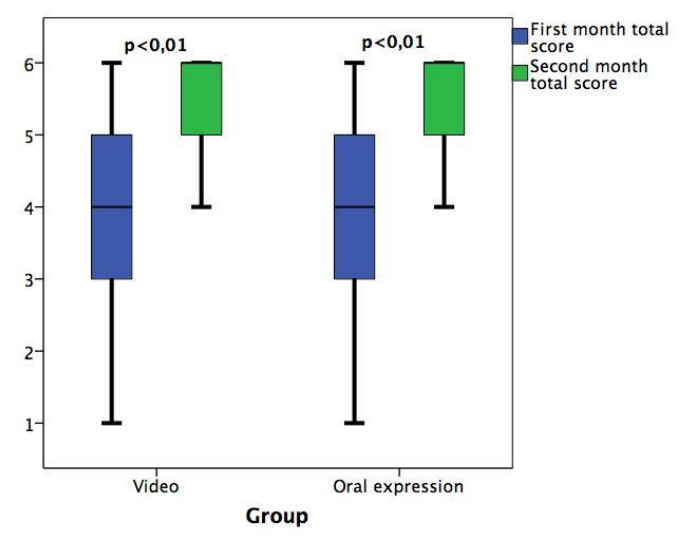

Figure 1:The total scores of both groups at the first and second month. ( $p<0,01$. Paired Sample t Test).

Moreover, they stressed that improper techniques cause higher treatment costs by increasing emergency hospital admissions and hospitalizations ${ }^{12}$. Giraud et al reported that errors of inhaler use were highly prevalent among patients with asthma, negatively affecting asthma control ${ }^{13}$. Kshatriya et al reported that even intern doctors committed technical errors about the use of inhaler medications ${ }^{14}$. Even residents of pediatrics department committed technical errors in a study by Benjaponpitaket $\mathrm{al}^{15}$. Since even doctors are deficient in use techniques, the results we find in our patients should not be surprising. Our work which emphasizes the need for repeated re-education may be the contribution of the literature to this issue.

Among the scientific society there is a huge interest in proper use of inhalers in asthma. Many articles on this subject have been published. Sanchis et al mentioned the proper inhaler technique in great detail ${ }^{16}$. However, some studies reported that errors are still prevalent despite repeated trainings for use ${ }^{17}$. 
One important point to mention is that a proper medication use by an appropriate technique boosts patient satisfaction ${ }^{18}$. Moreover, proper use of medications improves lung function ${ }^{19}$. Guss et al stated that inhaler drugs have the same effect as the nebulized ones when appropriate technique is performed ${ }^{20}$. Fernandez et al revealed in their studies that there would be an increase in proper use of drugs by means of education ${ }^{21}$. Aydemir et all mentioned the successful outcomes of face-toface training for correcting errors with inhaler use $^{22}$. Haidel et al reported that the most proper use of inhaler medications was by spacer use ${ }^{23}$. Takaku et all attempted to minimize technical errors by providing patients with three training sessions, which proved useful $^{24}$. Repeated training may be the best method if the purpose of education is to increase the efficiency as all these studies support.

In conclusion, we have actively involved our patients in the education process for the metered dose inhaler use in asthma. In this way, we have encouraged our patients to become aware of the treatment. Thus, we showed that the results would be better in their education. Our aim was to contribute to the education of asthma in the literature.

\section{Declaration of Conflicting Interests:} Theauthors declare that they have no conflict of interest.

Financial Disclosure: No financial supportwas received.

\section{KAYNAKLAR}

1. Price D, Bosnic-Anticevich S, Briggs A, et all. Inhaler competence in asthma: common errors, barriers to use and recommended solutions. Respir Med 2013; 107: 37-46.

2. Chorão P, Pereira AM, Fonseca JA. Inhaler devices in asthma and COPD--an assessment of inhaler technique and patient preferences. Respir Med 2014; 108: 96875.

3. Braido F, Chrystyn H, Baiardini I, et all. "Trying, But Failing" - The Role of Inhaler Technique and Mode of
Delivery in Respiratory Medication Adherence. J Allergy Clin Immunol Pract 2016; 4: 823-32.

4. Sanchis J, Gich I, Pedersen S; Aerosol Drug Management Improvement Team (ADMIT). Systematic Review of Errors in Inhaler Use: Has Patient Technique Improved Over Time? Chest 2016; 150: 394-406.

5. Marguet C, Couderc L, Le Roux P, et all. Inhalation treatment: errors in application and difficulties in acceptance of the devices are frequent in wheezy infants and young children. Pediatr Allergy Immunol 2001; 12: 224-30.

6. Turkeli A, Yilmaz 0, Yuksel H. Metered dose inhalerspacer use training effects on achieve asthma control in children. Tuberk Toraks 2016; 64: 105-11.

7. Dekhuijzen PN, Bjermer L, Lavorini F, et all. Guidance on handheld inhalers in asthma and COPD guidelines. Respir Med 2014; 108: 694-700.

8. Melzer AC, Ghassemieh BJ, Gillespie SE, et all. Patient characteristics associated with poor inhaler technique among a cohort of patients with COPD. Respir Med 2017; 123: 124-30.

9. Arora P, Kumar L, Vohra V, et all. Evaluating the technique of using inhalation device in COPD and bronchial asthma patients. Respir Med 2014; 108: 9928.

10. Oliveira PD, Menezes AM, Bertoldi AD, Wehrmeister FC, Macedo SE. Assessment of inhaler techniques employed by patients with respiratory diseases in southern Brazil: a population-based study. J Bras Pneumol 2014; 40: 513-20.

11. Mason N, Roberts N, Yard N, Partridge MR. Nebulisers or spacers for the administration of bronchodilators to those with asthma attending emergency departments? Respir Med 2008; 102: 993-8.

12. Melani AS, Bonavia M, Cilenti V, et all. Gruppo Educazionale Associazione Italiana Pneumologi Ospedalieri. Inhaler mishandling remains common in real life and is associated with reduced disease control. Respir Med 2011; 105: 930-8.

13. Giraud V, Allaert FA, Roche N. Inhaler technique and asthma: feasability and acceptability of training by pharmacists Respir Med 2011; 105: 1815-22.

14. Kshatriya RM, Khara NV, Paliwal RP, Patel SN. Evaluation of proficiency in using different inhaler devices among intern doctors. J Family Med Prim Care 2016; 5: 362-66.

15. Benjaponpitak S, Kraisarin C, Direkwattanachai C, Sasisakunporn C. Incorrect use of metered dose inhaler by pediatric residents. J Med Assoc Thai 1996; 79: 1226.

16. Sanchis J, Corrigan C, Levy ML, Viejo JL; ADMIT Group. Inhaler devices - from theory to practice. Respir Med 2013; 107: 495-502.

17. Dekhuijzen PN, Vincken W, Virchow JC, et all. Prescription of inhalers in asthma and COPD: towards a 
rational, rapid and effective approach. Respir Med 2013; 107: 1817-21.

18. Chrystyn H, Small M, Milligan G, et all. Impact of patients' satisfaction with their inhalers on treatment compliance and health status in COPD. Respir Med 2014; 108: 358-65.

19. Rahmati H, Ansarfard F, Ghodsbin F, Ghayumi MA, Sayadi M. The Effect of Training Inhalation Technique with or without Spacer on Maximum Expiratory Flow Rate and Inhaler Usage Skills in Asthmatic Patients: A Randomized Controlled Trial. Int J Community Based Nurs Midwifery 2014; 2: 211-9.

20. Guss D, Barash IA, Castillo EM. Characteristics of spacer device use by patients with asthma and COPD. J Emerg Med 2008; 35: 357-61.
21. Leiva-Fernández J, Leiva-Fernández F, VázquezAlarcón RL, et all. Study protocol for a randomized, controlled trial comparing the efficacy of two trainingal interventions to improve inhalation techniques in patients with chronic obstructive pulmonary disease (COPD): TIEPOC Study. Drugs Context 2014; 3: 212261.

22. Aydemir Y. Assessment of the factors affecting the failure to use inhaler devices before and after training. Respir Med 2015; 109: 451-8.

23. Haidl P, Heindl S, Siemon K, Bernacka M, Cloes RM. Inhalation device requirements for patients' inhalation maneuvers. Respir Med 2016; 118: 65-75.

24. Takaku Y, Kurashima K, Ohta C, et all. How many trainings are required to correct inhalation errors in patients with asthma and chronic obstructive pulmonary disease? Respir Med 2017; 123: 110-15. 